\title{
Süt serumu proteinlerinin in vitro koşullardaki antioksidan etkileri
}

\author{
Ayliz Velioğlu Öğünç¹, A.Süha Yalçın²
}

ÖZET: Kesilmiş sütün sıvı kısmı olan süt serumu (whey) sütün tedavi edici etkilerinden sorumlu tutulmaktadır. Peynir yapımı sırasında sütten ayrılan ve süt serumu veya 'peynir altı suyu' olarak da adlandırılan sıvının süt serumu proteinlerince zengin olduğu bilinmektedir. Bu yan ürün gıda endüstrisinde toz haline getirilerek kullanılmakta ve peynir altı suyu tozu (PAST) olarak adlandırılmaktadır. Çalışmalarımızda iki farklı yöntemle elde edilmiş süt serumu örnekleri kullanıldı. Birincisi günlük, taze ve pastörize edilmemiş inek sütünden elde edilen süt serumu, diğeri ise peynir yapımı sırasında elde edilen ve liyofilize edilerek endüstriyel bir gıda ürünü olarak satılan peynir altı suyu tozu (PAST) idi. Çalışmamızda bu ürünlerin, bakır ile oksidasyonu indüklenmiş insan serumunda lipit peroksidasyonuna ve protein oksidasyonuna olan etkisinin karşılaştırılması amaçlandı. Deneylerimizde; süt serumu proteinlerinde total ve serbest -SH grubu ölçümü, serumda lipit peroksidasyonu ölçümü (TBARS ve Dien Konjugasyon yöntemleriyle) ve serumda protein oksidasyonu ölçümü (protein karbonilleri) yöntemleri kullanıldı. Bu örneklerin protein miktarları Bradford yöntemi ile belirlendi. Sonuç olarak, PAST ve çiğ süt serumunun okside serum üzerine direk antioksidan etkisi olduğu ve bu etkinin içerdikleri -SH grubu miktarı ile ilişkili olduğu saptandı. -SH miktarı daha yüksek olan PAST’ın çiğ süt serumundan daha güçlü antioksidan etkiye sahip olduğu görüldü.

ANAHTAR KELIMELER: Süt Serumu Proteinleri, Whey, Antioksidan, Lipit peroksidasyonu

\section{GiRiş}

Beslenmenin genel sağlık durumuna etkisini, özellikle de bazı gıdaların tedavi edici etkilerini aydınlatabilmek için son yıllarda giderek artan sayıda araştırma yapılmaktadır. Süt, hastalık tedavi edici nitelik taşıdı̆̆ı düşünülen gıdalar arasında öne çıkmakta ve özellikle sütün 'süt serumu' fraksiyonunun bu etkinin asıl sorumlusu olduğu öne sürülmektedir. Süt serumu $\beta$-laktoglobulin, $\alpha$-laktalbumin, serum albumin, ve immunoglobulinlerden oluşan bir protein karışımıdır. Çok sayıda çalışmada süt serumunun çok yönlü terapötik etkileri aydınlatılmış ve bu protein karışımının antikanserojen ve serbest radikal hasarını önleyen etkileri öne çıkmıştır $(1,2)$.

Süt serumu, kazeini içeriği çöktürülmüş sütün sıvı kısmı olarak tanımlanabilmekle beraber, aslında peynir yapımı sırasında elde edilen bir yan üründür (3). İngilizce terminolojide 'whey' olarak adlandırılan bu ürünün dilimizdeki karşılı̆̆ 'süt serumu' veya 'peynir altı suyu'dur. Peynir altı suyunun liyofilize edilerek toz haline getirilmiş şekli (peynir altı suyu tozu-PAST) gıda endüstrisinde kullanılmaktadır.
Serbest radikaller hücre ve dokularda bir çok zarara yol açarak, akut ve kronik hastalıkların etiyolojisinde önemli bir rol oynarlar. Bu nedenle hastalık tedavisi için organizmanın kendi antioksidan kapasitesini güçlendirecek çözümler bulmak günümüzde çok sayıda bilimsel araştırmanın ana hedefidir. Süt serumu proteinlerinin antikanserojen ve bağ1şıklığı destekleyen etkileri çok sayıda in vivo araştırmada bildirilmiştir. Bu bulgular nedeniyle süt serumu proteinlerinin hastalik tedavisini destekleyen etkileri, organizmadaki antioksidan kapasiteyi bir yolla arttırmasıyla açıklanmaya çalışılmıştır. En çok üzerinde düşünce birliği olan hipotez, süt serumu proteinlerinin organizmada glutatyon (GSH) düzeyini arttırarak antioksidan etki gösterdiği düşüncesidir $(2,4,5)$. Aynı hipotez üzerinde planlanan in vitro çalışmalarda ise süt serumu proteinlerinin çeşitli yağ emülsiyonlarında lipit peroksidasyonunu gerilettiği gösterilmiştir $(6,7)$.

Çalışmamızda süt serumu proteinlerinin antioksidan etkilerini in vitro koşullardaki bulgularımızla aydınlatmayı hedefledik. Endüstriyel bir yan ürün olan PAST ile taze çiğ sütten elde ettiği-
KURUM

1Marmara Üniversitesi, Sağlık Hizmetleri MeslekYüksek Okulu, İstanbul, Türkiye 2Marmara Üniversitesi, Tıp Fakültesi, Biyokimya AD,

İstanbul, Türkiye

ILETIŞIM

Ayliz Velioğlu Öğünç

E-posta: avogunc@ marmara.edu.tr

Gönderilme:

05.12.2010

Revizyon:

12.12.2010

Kabul:

16.12.2010

Bu çalışma, Marmara

Üniversitesi Bilimsel Araştırma Projeleri Komisyonu Başkanlığı'nca (BAPKO) desteklenmiştir. 
TABLO 1. \%5 PAST ve Çiğ Süt Serumu örneklerinin ısıtma sonucunda serbest -SH miktarlarındaki değişim (mmol/l.gr protein)

\begin{tabular}{lcc}
\hline Sıcaklıklar & \%5 PAST Çözeltisi & Çiğ Süt Serumu \\
\hline $25^{\circ} \mathrm{C}$ & 0.20 & 0.12 \\
$50^{\circ} \mathrm{C}$ & 0.23 & 0.13 \\
$60^{\circ} \mathrm{C}$ & 0.21 & 0.13 \\
$70^{\circ} \mathrm{C}$ & 0.32 & 0.20 \\
$80^{\circ} \mathrm{C}$ & 0.52 & 0.40
\end{tabular}

miz süt serumu örneklerinin in vitro etkilerini de birbirleriyle karşılaştırdık. PAST ve çiğ süt serumu örneklerinin serbest sülfidril (-SH) gruplarının miktarlarını belirledikten sonra 1sıtılmış örneklerde -SH miktarında bir değişim olup olmadığını araştırdık. Aynı örneklerin sağlıklı insan serumunda bakır ile uyarılan lipit peroksidasyonunu ve protein oksidasyonunu ne yönde etkilediğini ve isıtma işleminin örneklerdeki antioksidan etkinliği ne şekilde değiştireceğini araştırmayı hedefledik.

\section{GEREÇ VE YÖNTEM}

Çalışmalarımızda iki farklı yöntemle elde edilmiş süt serumu örnekleri kullanıldı. Birincisi günlük, taze ve pastörize edilmemiş inek sütünden elde edilen süt serumu, diğeri ise peynir yapımı sırasında elde edilen ve liyofilize edilerek endüstriyel bir gıda ürünü olarak satılan peynir altı suyu tozu (PAST) idi.

\section{Süt serumu proteinlerinin çiğ inek sütünden eldesi}

Çalışmamızda, çiğ inek sütünden öncelikle kazein fraksiyonu asitle çöktürüldü ve sonra diyaliz uygulanarak süt serumu elde edildi. Protein saflaştırmasında uygulanan bir yöntem olan diyaliz yönteminde, protein çözeltisi yarı-geçirgen bir membran torba içine doldurulur. Bu membran uygun derişimde bir tampon içine yerleştirildikten sonra, küçük moleküller membrandan geçerek tampon ortamına karışırken, membran-

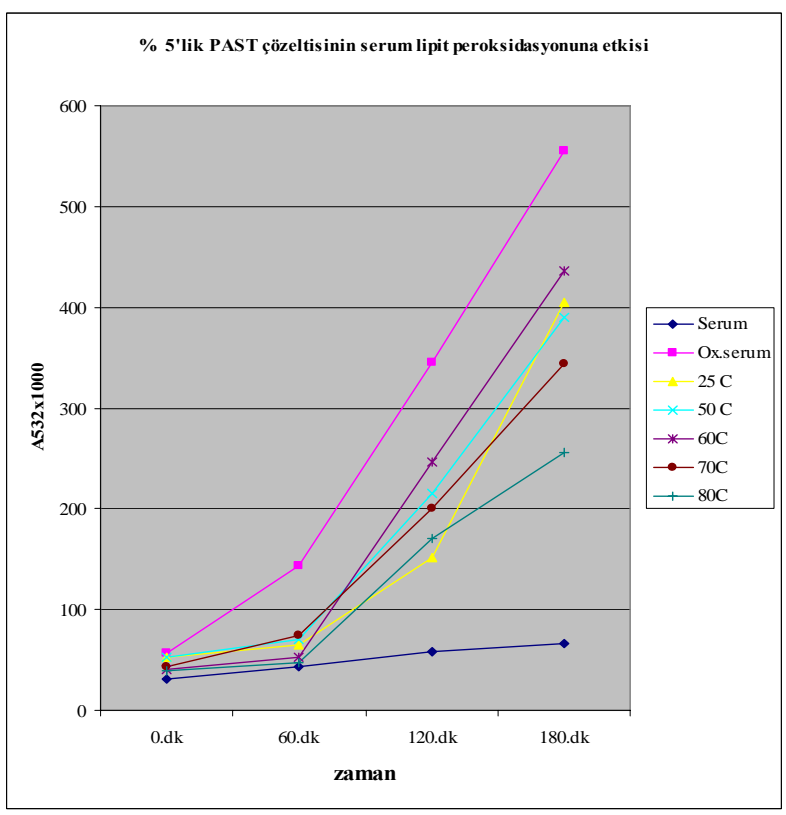

ŞEKiL 2. \%5'lik PAST çözeltisinin ve Istıtılan örneklerinin okside serumda lipit peroksidasyonuna (TBARS) etkisi

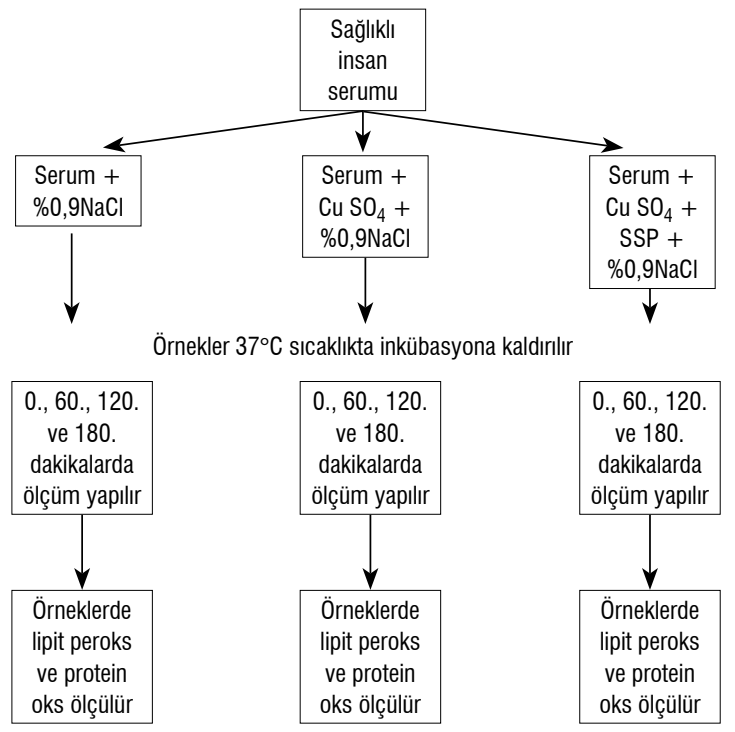

ŞEKiL 1. Bakır ile serum oksidasyonunun genel uygulama diyagramı

dan geçemeyen büyük moleküller torba içinde yoğunlaşırlar. Elde edilen süt serumu $-20^{\circ} \mathrm{C}^{\prime}$ de korundu(8).

\section{PAST'daki süt serumu proteinlerinin çözelti haline getirilmesi}

Kazein dışındaki süt proteinlerini içeren peyniraltı suyu peynir yapımı sırasında yan ürün ve atık olarak oluşmaktadır. Bahçıvan Gıda Sanayi ve Ticaret A. Ş.'den temin edilen PAST'dan PBS (pH 7.4) ile \% 5 'lik, \% 10'luk ve \%20'lik çözel-

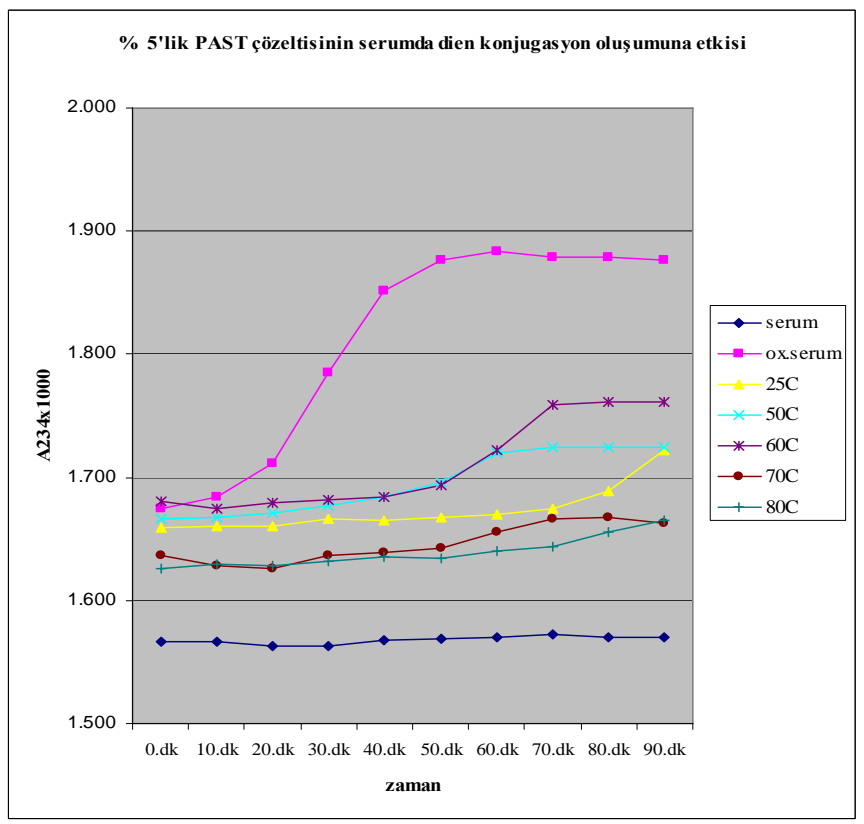

ŞEKiL 3. \%5'lik PAST çözeltisinin ve ısıtılan örneklerinin okside serumda dien konjugasyonuna etkisi 


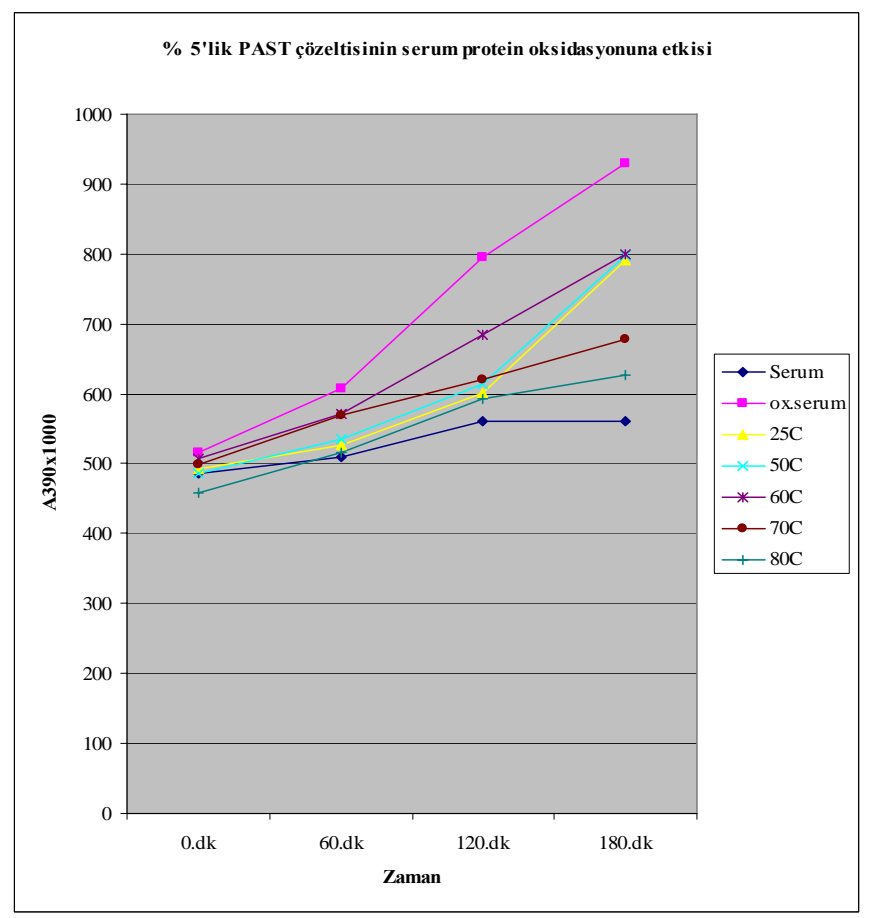

ŞEKiL 4. \% $5^{\prime}$ lik PAST çözeltisinin ve ısıtılan örneklerinin okside serumda protein oksidasyonuna etkisi

tiler hazırlandı. Ön denemelerden sonra, deneylerimiz için uygun konsantrasyonun $\% 5$ olduğuna karar verildi.

\section{PAST çözeltisi ve çiğ süt serumunun artan sıcaklıklarda Isıtılması}

Süt serumu proteinlerinin artan sıcaklıklarda isttılmasınin, antioksidan özellikleri üzerine etkisini aydınlatabilmek için, deneylerimizde çiğ süt serumu ile \% 5'lik PAST çözeltisi örnekleri $15^{\prime}$ er dakika süre ile $50,60,70$ ve $80^{\circ} \mathrm{C}$ sicaklıktaki su banyosunda isitıld1. Sonraki deneylerde bu örnekler de kullanıldı.

\section{Bradford yöntemi ile protein tayini}

Süt serumu örneklerimizdeki protein tayini, Bradford yöntemi ile yapıldı. Oldukça duyarlı olan bu yöntem $(5-100 \mathrm{mg} / \mathrm{ml})$; organik boyaların, proteinlerin asidik ve bazik grupları ile etkileşerek, renk oluşturmasını esas alır. Sonuç hesaplaması, sığır serum albumini ile hazırlanan standart eğrisinden yararlanılarak yapıldı (9).

\section{Protein sülfidril (-SH) gruplarının tayini}

Örneklerimizdeki serbest ve total -SH grupu tayini, Ellman metodunun bir modifikasyonu ile gerçekleştirildi. Ekstinksiyon katsayısı (e=13.600 M.L-1. $\left.\mathrm{cm}^{-1}\right)$ kullanılarak hesapland, sonuçlar mmol/L olarak ifade edildi $(10,11)$.

Süt serumu proteinlerinin, $\mathrm{CuSO}_{4}$ ile indüklenen serum lipit peroksidasyonuna etkisinin TBARS yöntemi ile ölçümü

$\mathrm{Cu}^{+2^{\prime}}$ in plazma lipoproteinleri için bir oksidan olmasından yararlanılarak $\mathrm{CuSO}_{4}$ ile okside edilmiş serum veya plazma örneğinde TBARS değerinin süt serumlarının varlığında değişimini spektrofotometrik olarak $535 \mathrm{~nm}$ 'de incelendi. Sağlıklı taze insan serumu, PAST'nun 0.5 M PBS (pH 7.4) içinde hazırlanmış \%

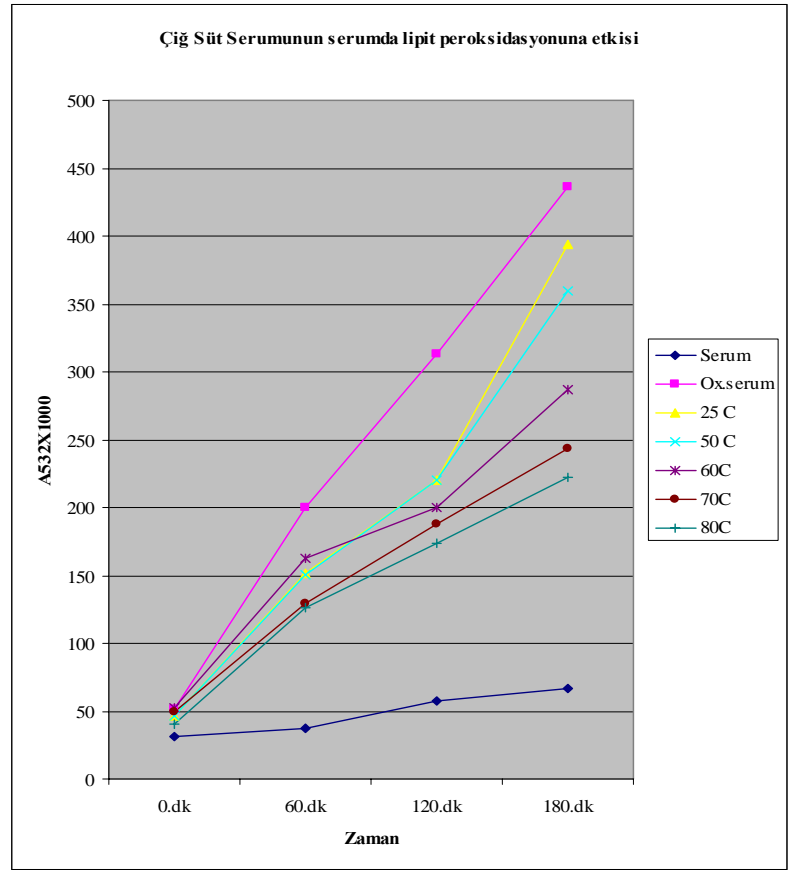

ŞEKiL 5. Çiğ süt serumunun ve ısıtılan örneklerinin okside serumda lipit peroksidasyonuna (TBARS) etkisi

$5^{\prime}$ lik çözeltisi, çiğ süt serumu ve her iki örneğin 50, 60, 70, ve $80^{\circ} \mathrm{C}^{\prime}$ de 1 sıtılmış örnekleri taze olarak kullanıldı $(12,13)$.

\section{Süt serumu proteinlerinin serumda dien konjugasyona etkisi}

Lipit hidroperoksitlerindeki konjuge dien yapılarının 234 nm'deki absorbanslarının zamana karşı ölçümü, lipoprotein oksidasyonunun karakterize edebilen kullanışlı bir yöntemdir. Deneylerimizde taze sağlıklı insan serumu, 0,5 M PBS $(\mathrm{pH}=7.4)$ ile \% 0.67 oranında sulandırılarak dien konjugasyon ölçümleri yapıldı $(14,15)$.

\section{Süt serumu proteinlerinin protein oksidasyonuna etkisi}

Süt serumu proteinlerinin antioksidan etkilerini daha geniş çerçevede değerlendirebilmek için bu proteinlerin serumdaki protein oksidasyonuna olan etkisi de araştırıldı. \% 5'lik PAST çözeltisi ve çiğ süt serumu örnekleri ve taze insan serumu 1/10 oranında sulandırılarak kullanıldı $(16,17)$.

\section{SONUÇ}

Çiğ süt serumu ve \% 5'lik PAST çözeltisinin protein, serbest ve total -SH ölçümleri yapıldı. \% 5'lik PAST . çözeltisinin protein miktar $95 \mathrm{~g} / \mathrm{l}$, çiğ süt serumunun ise $227.2 \mathrm{~g} / 1$ olarak belirlendi . Çiğ süt serumununun \% 5'lik PAST çözeltisinden daha fazla miktarda protein içermesine karşın, gram protein başına daha az -SH grubu içerdiği görüldü. Total $-\mathrm{SH}$ ölçümleri sonucunda \% 5'lik PAST çözeltisinde $0.7 \mathrm{mmol} / \mathrm{g}$. protein, çiğ süt serumunda ise $0.57 \mathrm{mmol} / \mathrm{g}$. protein -SH bulunduğu belirlendi. Ayrıca 50, 60, 70 ve $80^{\circ} \mathrm{C}$ sıcaklıklarda ısıtılmış örneklerin serbest -SH ölçümleri yapıldı. Isıtma işleminin örneklerdeki serbest-SH miktarını arttırdığı görüldü (Tablo 1). 


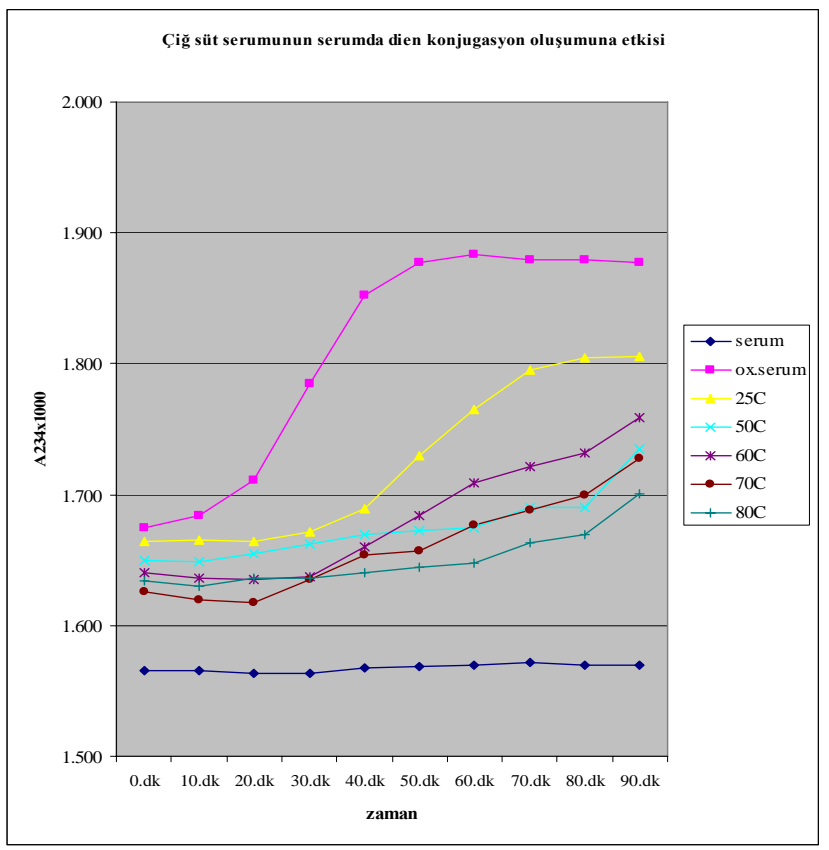

ŞEKiL 6. Çiğ süt serumunun ve ısıtılan örneklerinin okside serumda dien konjugasyon oluşumuna etkisi

\section{\% 5'lik PAST çözeltisinin ve ısıtılan örneklerinin okside serumda lipit peroksidasyonuna ve protein oksidasyonuna etkisi}

$\mathrm{CuSO}_{4}$ ile okside edilen serumda \%5'lik PAST çözeltisinin lipit peroksidasyonu ve protein oksidasyonunu kontrole göre belirgin biçimde gerilettiği görüldü. PAST örneklerimizin serumda lipit peroksidasyonuna olan etkisi hem TBARS hem de dien konjugasyon oluşumunun baskılanması ile belirgin şekilde saptanırken, 1sitılmamış $\left(25^{\circ} \mathrm{C}\right), 50$ ve $60^{\circ} \mathrm{C}$ isitılmış örneklerin etkilerinin birbirlerine oldukça yakın olduğu gözlendi. 70 ve $80^{\circ} \mathrm{C}^{\prime}$ de isitılan örneklerin, lipit peroksidasyonuna olan etkisinin serbest -SH değişimine benzer biçimde arttı̆̆ saptand1. Üç saat süresince yapılan lipit peroksidasyon ölçümlerinde PAST örneklerinin antioksidan etkisi 120. dakika itibariyle daha da belirginleşti. PAST örneklerinin serum lipit peroksidasyon (TBARS) ve dien konjugasyon olan etkisi Şekil 2 ve Şekil 3'de grafiklerle gösterilmiştir.

PAST örneklerinin okside serumda protein oksidasyonuna olan etkisi incelendiğinde, PAST örneklerinin serum protein oksidasyonunu baskıladığı, 70 ve $80^{\circ} \mathrm{C}$ 1sitılan örneklerde bu etkinin en yüksek düzeyde olduğu belirlendi. Şekil 4'de PAST örneklerinin serum protein oksidasyonuna olan etkisi grafikle gösterilmiştir. Tüm örneklere ait ölçümler 4 kez tekrarlanıp, hesaplanan ortalama değerlerle grafikler oluşturulmuştur.

\section{Çiğ süt serumunun ve ısıtılan örneklerinin okside serumda lipit peroksidasyonuna ve protein oksidasyonuna etkisi}

$\mathrm{CuSO}_{4}$ ile okside edilen serumda çiğ süt serumunun serum lipit peroksidasyonu ve protein oksidasyonunu kontrole göre belirgin biçimde baskıladığı görüldü. Isıtılan örneklerde uygulanan sıcaklık arttıkça (70 ve $80^{\circ} \mathrm{C}^{\prime}$ de en belirgin şekilde), lipit peroksidasyonuna olan etkinin serbest -SH değişimine benzer biçimde arttığı saptandı. Serum protein oksidasyonuna olan etki sıcaklık artışı ve -SH artışına çok fazla paralel olmamakla

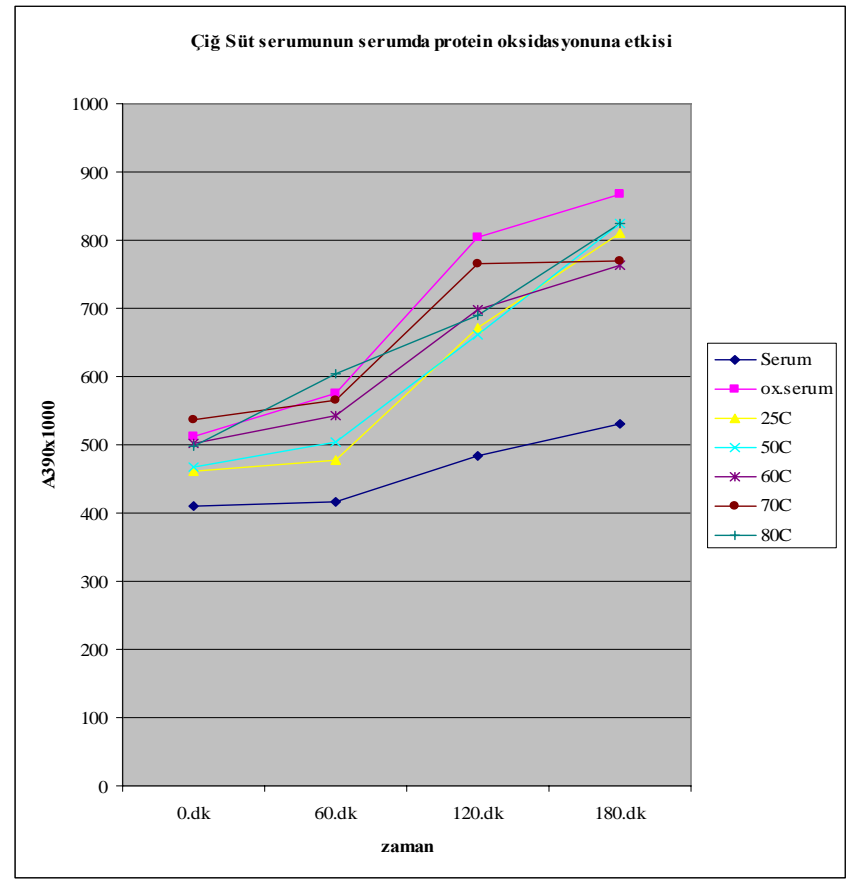

ŞEKiL 7. Çiğ süt serumunun ve ısıtılan örneklerinin okside serumda protein oksidasyonuna etkisi

birlikte 70 ve $80^{\circ} \mathrm{C}$ isıtılmış örneklerde 180 . dakikada en yüksek düzeyde saptandı. Çiğ süt serumunun lipit peroksidasyonunu ve protein oksidasyonunu baskılayan etkisinin, \% 5'lik PAST çözeltisine kıyasla daha az olduğu görüldü. Şekil 5 ve Şekil 6'da çiğ süt serumu örneklerinin serum lipit peroksidasyon ve dien konjugasyonuna etkisi, Şekil 7 'de ise serum protein oksidasyonuna etkisi grafiklerle gösterilmiştir. Tüm örneklere ait ölçümler $4 \mathrm{kez}$ tekrarlanıp, hesaplanan ortalama değerlerle grafikler oluşturulmuştur.

\section{TARTIŞMA}

Süt tüm ana besin unsurlarını ve organizmanın metabolik işlevleri için gerekli vitamin, enzim ve eser elementleri içeren bir besin maddesidir. Sütün tedavi edici etkisini araştıran çalışmalarda, süt içinde çok miktarda antioksidan molekülün bulunduğu belirlenmiştir. Bu moleküller sütün işlenmesi sırasında kısmen ya da tamamen kayba uğrayarak, sütün insanlar tarafından tüketime uygun hale getirilen ticari formlarının antioksidan moleküller açısından daha fakir bir gıdaya dönüşmesine yolaçmaktadır $(3,18)$.

Süt proteinleri kazeinler ve süt serumu proteinlerinden oluşmaktadır. Son yıllarda giderek artan sayıda araştırmada sütün tedavi edici etkilerinin olduğu ve bu etkinin süt proteinlerinden kaynaklandığı gösterilmiştir. Süt proteinlerinin tedavi edici etkileri önceleri antioksidan, antikanserojen ve antitumoral etkiler olarak sinırlanırken, günümüzde antihipertansif, antimikrobiyal, bağışıklık destekleyici, kas yapılandırıcı etkileri de bildirilmiştir (19-23).

Süt proteinlerinin tedaviye etkileri araştırılırken, sütün 'süt serumu' fraksiyonunda bulunan çözünür proteinlerin (Süt serumu proteinleri-SSP), kazeinlere göre daha belirgin ve daha geniş spektrumlu etkileri öne çıkmaktadır. Kazeinlerin etkileri 
bildirilmiş olsa da, bu çok az sayıda in vitro araştırma ile gösterilebilmiştir. Ayrıca kazeinlerin SSP ile karşılaştırmalı olarak araştırıldığı çalışmalarda, kazeinlerin tedavi edici etkilerinin SSP'e göre anlamlı biçimde düşük olduğu bildirilmiştir (24).

SSP'nin hastalık tedavi edici etkilerinin belirlenmesi ile, sütün asıl terapötik değerinin süt serumunda saklı olduğu şüphe götürmez hale gelmiştir. Bu nedenle çalışmamızda sütün antioksidan etkilerini araştırırken, peyniraltısuyu tozu olarak isimlendirilen, aslında peynir yapımı sırasında ayrılan süt serumunun toz formu olan bir gida ürününü kullanıldı.

SSP'nin tedavi edici etkileri ortaya konulurken, bu etkilerdeki biyokimyasal mekanizmalar halen aydınlanmamıştır. SSP ile beslenen kanser ve tümör modeli oluşturulmuş sıçanlarda saptanan antikanserojen etki, organizmanın antioksidan savunmasının ve bununla bağlı olarak bağışıklık sisteminin güçlenmesi ile açıklanmıştır $(23,25,26,27)$. SSP'nin bağışıklığı destekleyen etkisi, hücre GSH düzeyinin artışıyla ilişkilendirilirken $(20,22,28,29)$, antikanser etkiyi süt serumundaki laktoferrinin GSH'dan bağımsız etkisiyle açıklayan bulgularda bulunmaktadır (30).

SSP'nin antikanserojen etkilerini gösteren çalışmaların sonucunda birbirinden farklı kanserli-hücre kültürlerindeki araştırmalardan, sıçanlarda oluşturulmuş çok sayıda kanser modelini de kapsayan oldukça geniş bir bulgu havuzu oluşmuştur $(23,29,31,32)$.

Beslenme yoluyla alınan proteinlerin aminoasit kompozisyonlarının organizmada bazı moleküllerin sentezini etkileyebileceği bildirilmiştir. Esansiyel aminoasitlerden ve sülfür içeren aminoasitlerden zengin bir protein kaynağı ile beslenmenin organizmanın humoral immun yanıtını kuvvetlendireceği (25), GSH sentezini düzenleyeceği, organizmanın büyüme ve gelişimini hızlandıracağı bildirilmiştir $(2,5)$.

SSP'nin antioksidan etkilerini araştıran in vitro çalışmalarda, SSP izolatlarının (WPI) dondurulmuş gıdalarda oksidan hasarı önlediği, SSP konsentrelerinin (WPC) yağ emülsiyonlarında lipit peroksidasyonunu baskıladığı bildirilmiştir (33). In vitro bulgular SSP'nin lipit peroksidasyonunu önlediğine işaret ederken, in vivo bulguların çoğunluğu SSP ile beslenmenin doku GSH miktarını arttırdığını ileri sürmüştür.

SSP'nin böylesine karakteristik bir bulgularının asıl mekanizmasının in vitro deneylerle aydınlatılabileceği düşünülerek, çalışmamızda PAST ve çiğ süt serumunun tiyol (-SH grupları) içeriği ve bu örneklerin oksidasyonu indüklenen sağlıklı insan serumundaki antioksidan etkisi karşılaştırmalı biçimde araştırıldı.

PAST çözeltisi ile çiğ süt serumu örnekleri gram protein başına düşen -SH grubu miktarı olarak karşılaştırıldı ğında, PAST protein miktarı olarak çiğ süt serumunundan daha az protein içermesine karşın, daha fazla -SH grubu içermektedir. Bakır ile indüklenen serum lipit ve protein oksidasyonu üzerindeki etkileri değerlendirildiğinde, $\mathrm{PAST}^{\prime}$ ın çiğ süt serumuna göre daha güçlü bir antioksidan etkisinin olduğu görüldü. Çalışmamızda PAST'daki antioksidan etkinin yapısındaki tiyol gruplarına bağlı olup olmadığını, PAST ve çiğ süt serumunun artan sıcaklıklarda isıtılan örneklerinin antioksidan etkilerindeki değişimi araştırarak saptandı. Taylor'ın (33) çalışmasında da bildirildiği gibi, 1sıtılan süt serumu örneklerinde reaktif -SH grupları artışı bu antioksidan etkiyi arttırmaktadır. Bizim çalışmamızdaki bul- gularda, literatüre uygun biçimde isıtılan örneklerde antioksidan etki artmakta, bu etki molekülün denatürasyonunun başladığ 70 ve $80^{\circ} \mathrm{C}^{\prime}$ de maksimum düzeye ulaşmaktadır.

SSP 1sıtmaya karşı yüksek dayanıklılığı olan proteinlerdir. Özellikle $\beta$-laktoglobulin $65^{\circ} \mathrm{C}$ ve üzeri sicaklıklarda reaktif $\mathrm{SH}$ gruplarının ortaya çıkışı ile başka proteinlerle veya moleküllerle reaksiyona girme, disülfit köprüsü oluşturma potansiyeli artar $(30,34)$. -SH içeriği açısından süt serumu proteinleri arasındaki tek etkin protein $\beta$-laktoglobulin değildir. $\alpha$-Laktalbumin ve serum albumin de -SH grupları içermektedir ve serum albuminin sülfidril-disülfid değişim indeksi (SEI)'nin $\beta$-laktoglobulin'den 100-1052 kat fazla olduğu bildirilmiştir (35).

SSP'nin lipit peroksidasyonunu önleyen etkisinin proteinlerindeki tiyol gruplarına bağlı olduğunu gösterebilmek için Tong'un (36) çalışmasında N-etilenmaleimid'in (NEM) -SH gruplarını bloke edebilme özelliğinden yararlanılarak, NEM varlığında süt serumunun lipit peroksidasyonunu önleyen etkisinin ortadan kalktığı bildirilmiştir.

Sağlıklı insan plazmasında Cu ile uyarılan LDL oksidasyonunun, bir flavanoid karışımı olan Pycnogenol ile baskılandığı, süt serumu tozunun (Whey powder) tek başına LDL oksidasyonunu baskıladığını gösterirken, Pycogenol ile beraber uygulanması sonucunda güçlü bir additif etkinin oluştuğu görülmüştür (12). Bizim çalışma bulgularımıza çok benzer biçimde, süt serumu tozunun LDL oksidasyonunu baskılayan etkisi hem TBARS hem de dien konjugasyon yöntemi ile doğrulanmiştır.

In vitro bulgularımızın 1şığında, SSP'nin antioksidan etkisinin büyük ölçüde -SH gruplarına bağlı olduğu ve bu proteinlerin 1sitılması ile reaktif -SH gruplarının ve biyoaktif peptidlerin ortaya çıkarak antioksidan etkiyi güçlendirdiği kanısındayız. PAST örneklerinin çiğ süt serumundan daha fazla miktarda $\mathrm{SH}$ içermesi sebebiyle daha fazla antioksidan etkiye sahip olduğu düşüncesindeyiz. Bulgularımız yorumlandığında PAST'ın zengin bir sistein kaynağı olduğu, hücreler için GSH sentezini arttırıcı etki gösterebileceği ve dokularda radikal hasarına karşı antioksidan savunmayı güçlendirebileceği düşünülebilir. Ayrıca süt serumu proteinlerinin ısıtma ve enzimlerle hidroliz gibi işlemlerden geçtiğinde daha aktif moleküllere dönüşebileceği ve biyoaktif peptidlerin etkinleşeceği düşüncesindeyiz. SSP'nin antioksidan aktivitesinin 1sitma yoluyla arttırılabilmesi, bu proteinlerin biyoyararlanımının fiziksel ve biyokimyasal yollarla değiştirilebileceğini göstermektedir.

Sonuç olarak, süt serumu proteinlerinin dokuların serbest radikal hasarından korunmasında etkin bir koruyucu olabileceğini, PAST'in süt serumu konsantrelerine eşdeğer nitelikte bir tedavi edici potansiyel taşıdığını ve bu nedenle yalnızca bir gıda yan ürünü değil, günlük beslenme rutinimiz içindeki bir gıda olmasının gerekliliğini vurgulamaktayız. Mevcut bulgular ışığında, süt serumu proteinlerinin düzenli tüketiminin yalnızca bireyin oksidan hasardan korunmasında değil, genel sağlık durumunun iyileşmesine de olumlu katkı sağlayacağ söylenebilir. Ayrıca süt serumu proteinleri ile ilgili bulguların zenginleşmesi ve etki mekanizmalarının aydınlatılabilmesi için, sağlıklı insanlarda ve klinik uygulamalardaki etkilerin de görülebileceği çok sayıda araştırmaya gereksinim vardır. 


\section{Antioxidant effects of whey proteins in vitro}

SUMMARY: Whey is the liquid part which is responsible for the therapeutic effects of milk. Whey is a product of cheese manufacture and is rich in milk serum proteins. This by-product is powdered and used in the nutritonal industry. In recent years, increasing number of studies clarifying the multiple therapeutic effects of whey have appeared. Its protective effects on free radical damage and anticarcinogenic effects are the major ones among other beneficial effects. In this study, we have investigated preventive effects of whey proteins against lipid and protein oxidation of serum in vitro. We have used whey powder and raw liquid whey in our experiments. We determined their antioxidant effects against lipid and protein oxidation in human serum samples oxidized by $\mathrm{CuSO}_{4}$. Sulfhydryl (-SH) groups of heated and non-heated whey proteins was measured using a modification of the Ellman assay, lipid peroxidation by TBARS and Diene Conjugation methods and protein oxidation by protein carbonly method. Bradford Method was used in protein measurements of samples. In our in vitro experiments, we observed that the reactive sulphydryl group content is related to the antioxidant effects of whey proteins and -SH content of whey powder is higher than in raw milk serum. Therefore, whey powder has a stronger antioxidant effect than raw milk serum.

KEY WORDS: Whey proteins, whey, antioxidant, lipid peroxidation

\section{KAYNAKLAR}

1. Ewan H, Zemel MB. Functional properties of whey, whey components, and essential amino acids: mechanisms underlying health benefits for active people. J. Nutr. Biochem, 14: 251-258, 2003.

2. Bounous $G$, Batist $G$, Gold $P$. Immunoenhancing property of dietary whey protein in mice: role of glutathione. Clin Invest Med, 12: 154-161, 1989.

3. Ensminger AH, Ensminger ME, Konlande JE, Robson JRK. Milk and milk products. The Concise encylopedia of foods and nutrition. s. 691-710, CRC Press Inc, U.S.A, 1995.

4. Bounous $\mathrm{G}$. Whey protein concentrate (WPC) and glutathione modulation in cancer treatment. Anticancer Res, 20: 4785-4792, 2000.

5. Flagg EW, Coates RJ, Eley W et al. Dietary glutathione intake in humans and the relationship between intake and olasma total glutathione level. Nutr Cancer, 21: 3339, 1994.

6. Ramos EAP, Xiong YL. Antioxidative activity of whey protein hydrolysates in a liposomal system. J Dairy Sci, 84: 2577-2583, 2001.

7. Ramos EAP, Xiong YL. Whey and soy protein hydrolysates inhibit lipid oxidation in cooked pork patties. Meat Sci, 64: 259-263, 2003.

8. Harris ELV, Angal S. Protein purification methods. A practical approach. s. 30-55, IRL Press, Oxford, 1989.

9. Bradford MM. A rapid and sensitive method for the quantitation of microgram quantities of protein utilizing the principle of protein-dye binding. Anal Biochem, 72: 248-254, 1976

10. Ellman GL. Tissue sulfhydryl groups. Arc Biochem Biophys, 82: 70-77, 1959.

11. Patrick PS, Swaisgood HE. Sulfhydryl and disulfide groups in skim milk as affected by direct ultra-high temperature heating and subseguent storage. J Dairy Sci, 59: 594-600, 1975.

12. Janisch $K$, Hippeli $S$, Dornisch $K$, Kern S, Elstner EF. Determination of the antioxidative potential of human plasma after supplementation with pycnogenol and whey. Food Res Int, 35: 257-266, 2002.

13. Zhang A, Vertommen J, Van Gaal L, De Leeuw I. A rapid and simple method for measuring the susceptibility of low-density-lipoprotein and very-low density lipoprotein to copper-catalyzed oxidation. Clin Chim Acta, 227: 159-173, 1994.

14. Kontush A., Beisiegel U.: Measurement of oxidizability of blood plasma. Meth Enzymol, 299: 35-49, 1999.

15. Nyyssönen K, Sarataho EP, Kaikkonen J, Salonen JT. Ascorbate and urate are the strongest determinants of plasma antioxidative capacity and serum lipid resistance to oxidation in Finnish men. Atherosclerosis, 130: 223-233, 1997.

16. Haklar G, Erşahin Ç, Moini $H$ et al. Protective effects of cilazapril against free radical injury in myocardial ischaemia -reperfusion. Pharmacol Res, 31: 33-36, 1995.

17. Levine RL, Garland D, Oliver $C N$ et al. Determination of carbonyl content in oxidatively modified proteins. Meth Enzymol, 186: 465-478, 1990.

18. Lindmark-Mansson $H$, Akesson $B$. Antioxidative factors in milk. Br J Nutr, 84: 103-110, 2000.

19. Buttriss J, Milk ED, Macrae R et al. Encyclopaedia of food science, food technology, and nutrition. Vol: 5, s. 30663090, Academic Press, London, San Diego, 1993.

20. Bounous G, Kongshavn PAT. The effect of dietary amino acids on immune reactivity. Immunology, 35: 257-266, 1978.

21. Bounous G, Kongshavn PAT. Differential effect of dietary protein type on the B-Cell and T-Cell immune responses in mice. J Nutr, 115: 1403-1408, 1985.

22. Bounous $G$, Letourneau $L$, Kongshavn PAL. Influence of dietary protein type on immune system of mice. J Nutr, 113: 1415-1421, 1983.

23. Bounous $G$, Papenburg $R$, Kongshavn $P$ et al. Dietary whey protein inhibits the development of dimethylhydrazine induced malignancy. Clin Invest Med, 11: 213-217, 1988.

24. Cervato $G$, Cazzola $R$, Cestaro B. Studies on the activity of milk caseins. Int J Food Sci Nutr, 50: 291-296, 1999.

25. He F, Tuomola E, Arvilommi H, Salminen S. Modulation of human immune response through orally administered bovine colostrum. FEMS Immunol Med Microbiol, 31: 93-96, 2001. 
26. Low PPL, Rutherfurd KJ, Gill HS, Cross ML. Effect of dietary whey protein concentrate on primary and secondary antibody responses in immunized BALB/c mice. Int Immunopharm, 3: 393-401, 2003.

27. Micke P, Beeh KM, Buhl R. Effects of long-term supplementation with whey proteins on plasma glutathione levels of HIV-infected patients. Eur J Nutr, 41: 12-18, 2002.

28. Bounous $G$, Baruchel $S$, Falutz J, Gold P. Whey proteins as a food supplement in HIV seropositive individuals. Clin Invest Med, 16: 204-209, 1993.

29. Middleton $N$, Reid JR, Coolbear T, Jelen P. Proliferation and intracellular glutathione in Jurkat Tcells with concentrated whey protein products. Int Dairy J, 13: 565-573, 2003.

30. Tsuda $H$, Sekine $K$, Ushida $Y$ et al. Milk dairry products in cancer prevention: focus on bovine laktoferrin. Mutat Res, 462: 227-233, 2000.

31. Belobrajdic DP, McIntosh GH, Owens JA. Whey proteins protect more than red meat against azoxymethane induced ACF in Wistar rats. Cancer Lett, 198: 43-51, 2003.

32. Tsai $W Y$, Chang $W H$, Chen $C H$, Lu FJ. Enhancing effect of patented whey protein isolate (Immunucal) on cytotoxicity of an anticancer drug. Nutr Cancer, 38: 200-208,
2000.

33. Taylor JM, Richardson T. Antioxidant activity of skim milk: Effect of heat and resultant sulfhydryl groups. J Dairy Sci, 63: 1783-1795, 1980.

34. Alting AC, Hamer RJ, Kruif CG et al. Number of thiol groups rather than the size of the aggregates determines the hardness of cold set whey protein gels. Food Hydrocol, 17: 469-479, 2003.

35. Apenten RKO, Chee C, Hwee OP. Evaluation of a sulphydryl-disulphide exchange index (SEI) for whey proteins -b-lactoglobulin and bovine serum albumin. Food Chem, 83: 541-545, 2003.

36. Tong LM, Sasaki S, Mc Clements DJ, Decker EA. Mechanisms of the antioxidant activity of high molecular weight fraction of whey. J Agric Food Chem, 48: 1473-1478, 2000. 